Original Research Paper

\title{
Application of Simplex Lattice Design Method on The Optimisation of Deodorant Roll-on Formula of Ashitaba (Angelica keiskei)
}

\author{
Wahida Hajrin $^{1 *}$, Windah Anugrah Subaidah ${ }^{1}$, Yohanes Juliantoni1 ${ }^{1}$, Dyke Gita Wirasisya ${ }^{1}$ \\ ${ }^{1}$ Program Studi Farmasi, Fakultas Kedokteran, Universitas Mataram, Mataram, Indonesia
}

\author{
Article History \\ Received : June $11^{\text {th }}, 2021$ \\ Revised : June $25^{\text {th }}, 2021$ \\ Accepted : July $02^{\text {th }}, 2021$ \\ Published : July $06^{\text {th }}, 2021$ \\ *Corresponding Author: \\ Wahida Hajrin, \\ Program Studi Farmasi \\ Fakultas Kedokteran \\ Universitas Mataram, Mataram, \\ Indonesia \\ Email: \\ wahida08farm@gmail.com
}

\begin{abstract}
Ashitaba is known to have antioxidant activity and gram-positive antibacterial activity that causes body odor. This is the potential activity for an active substance to be developed as deodorant. The appropriate formula is needed, so it is necessary to optimize the formula using the right method. This study aimed was to determine the application of the simplex lattice design method on the optimization of a deodorant roll-on formula of ashitaba extract. Ashitaba was extracted by the maceration method. The formula optimization design was determined using the simplex lattice design method by Design Expert ${ }^{2} 7.5 .1$. The components for optimization were the concentration of carbopol and concentration of TEA, and the optimization parameters were the spreadability test, sticky power, and $\mathrm{pH}$ test. The optimum formula of deodorant consists of $0.45 \%$ carbopol and $2.05 \%$ TEA. The responses of optimum formula obtained spreadability test $6.32 \pm 0.33 \mathrm{~cm}$, sticky power $44.67 \pm 3.94$ seconds, and $\mathrm{pH} 7.73 \pm 0.17$. These results meet the criteria for good preparation but need further testing related to the effectiveness of the preparation and the level of acceptance of the preparation by the user.
\end{abstract}

Keywords: Ashitaba; Angelica keiskei; Deodorant roll-on; Optimization; Simplex lattice design.

\section{Pendahuluan}

Ashitaba (Angelica keiskei) telah diketahui memiliki berbagai kandungan senyawa seperti flavonoid, kumarin, fenolik, asetilen, sesquiterpene, diterpene, dan triterpene (Kil et al., 2017). Senyawa fenolik pada ashitaba didominasi oleh asam klorogenik, kalkon, dan glikosida flavonoid terdiri dari luteolin dan kuersetin (Li et al., 2009). Senyawa kalkon yang ada pada ashitaba adalah xanthoangelol (Enoki et al., 2007).

Kandungan senyawa pada ashitaba telah diteliti memiliki berbagai efek farmakologi, yaitu menghambat pertumbuhan sel tumor, menekan inflamasi, obesitas, diabetes, hipertensi, ulcer, anti trombotik, antioksidan, antihiperlipid, antivirus, dan anti bakteri (Kil et al., 2017). Efek antioksidan dan antibakteri merupakan efek yang dapat dimanfaatkan dalam pembuatan sediaan deodorant. Ashitaba diketahui memiliki efek antioksidan sebanding dengan peningkatan kadar senyawa fenoliknya (Zhang et al, 2019). Efek

This article is licensed under a Creative Commons Attribution 4.0 International License. antibakteri ashitaba terhadap bakteri gram positif disebabkan oleh adanya senyawa xanthoangelol, dengan nilai KHM pada bakteri $S$. aureus xanthoangelol sebesar $6,25 \mu \mathrm{g} / \mathrm{mL}$ (Inamori et al., 1991). Nilai KHM ekstrak ashitaba adalah $1,0 \mathrm{mg} / \mathrm{mL}$ (Suhartati dan Virgianti, 2015). Ashitaba juga dapat menghambat pertumbuhan bakteri Mycobacterium tuberculosis (Kusuma et $a l, 2018)$. Selain itu, ashitaba memiliki efek antibakteri Streptococcus mutans (Wirasisya et al., 2018).

Staphylococcus aureus merupakan salah satu bakteri gram positif yang banyak terdapat pada kulit. Keberadaan bakteri ini dapat menyebabkan bau badan. Salah satu cara yang dapat dilakukan untuk mencegah pertumbuhannya adalah dengan menggunakan deodorant. Deodorant merupakan sediaan yang digunakan untuk mencegah pertumbuhan bakteri penyebab bau badan pada daerah lipatan yang mengandung banyak kelenjar keringat. Bentuk deodorant beragam, seperti bentuk stik padat, roll on, dan spray (Paye et al., 2001). Masing- 
masing bentuk sediaan deodorant memiliki keuntungan dan kerugian. Bentuk roll on masih menjadi pilihan utama karena lebih praktis dalam pengaplikasiannya. Namun, formula yang tepat dibutuhkan untuk memenuhi sifat fisik dan stabilitas sediaan.

Metode simplex lattice design merupakan metode yang digunakan untuk megoptimasi formula pada berbagai perbedaan jumlah komposisi bahan, yang jumlah totalnya dibuat sama. Metode ini dapat menentukan formula optimum dengan menggunakan jumlah percobaan yang lebih sedikit sehingga dapat meminimalkan penggunaan bahan. Tujuan dari penelitian ini adalah mengetahui aplikasi metode simplex lattice design pada optimasi formula deodorant roll-on ekstrak ashitaba sehingga diperoleh formula deodorant roll-on ekstrak ashitaba yang memiliki sifat fisik sediaan yang baik.

\section{Bahan dan Metode}

\section{Bahan}

Bahan-bahan yang digunakan dalam penelitian ini adalah ekstrak Ashitaba, etanol 96\% (teknis), karbopol, trietanolamin, metil paraben, propilenglikol, aquadest.

\section{Pembuatan Ekstrak Ashitaba}

Tanaman Ashitaba diperoleh dari Desa Sembalun Kabupaten Lombok Timur. Tanaman dicuci bersih dengan air mengalir, dikeringkan, kemudian dirajang. Tanaman yang telah dirajang dikeringkan pada oven dengan suhu $40^{\circ} \mathrm{C}$. Simplisia yang telah kering diblender sehingga diperoleh serbuk simplisia Ashitaba. Serbuk simplisia diekstraksi dengan menggunakan metode maserasi menggunakan pelarut metanol. Maserasi dilakukan selama 1x24 jam. Maserat ditampung, ampas kemudian diremaserasi sebanyak 2x pengulangan. Gabungan maserat ditampung, pelarut diuapkan dengan rotary evaporator hingga diperoleh ekstrak kental.

\section{Formulasi Deodorant Roll-on Ekstrak Ashitaba}

Formula sediaan deodorant roll on ekstrak ashitaba seperti terlihat pada tabel 1 .
Tabel 1. Formula sediaan deodorant roll-on ekstrak ashitaba

\begin{tabular}{|l|c|}
\hline \multicolumn{1}{|c|}{ Bahan } & Jumlah (\%) \\
\hline Ekstrak ashitaba & 0,1 \\
\hline Karbopol 940 & $0,25-2,25$ \\
\hline Trietanolamin & $0,25-2,25$ \\
\hline Etanol 96\% & 40 \\
\hline Metil paraben & 0,1 \\
\hline Propilenglikol & 15 \\
\hline Aquadest $a d$ & 100 \\
\hline
\end{tabular}

Pembuatan sediaan deodorant roll on ekstrak ashitaba dilakukan dengan cara karbopol didispersikan pada aquadest panas hingga mengembang. Dibuat campuran etanol, propilen glikol, dan aquadest untuk melarutkan ekstrak Ashitaba dan metil paraben. Campuran tersebut dimasukkan dalam karbopol yang sudah mengembang dan diaduk hingga homogen. Selanjutnya trietanolamin ditambahkan pada campuran dan diaduk hingga homogen dan terbentuk gel.

\section{Uji Sifat Fisik Deodorant Roll-on Ekstrak Ashitaba}

1. Uji organoleptis

Uji organoleptis dilakukan dengan mengamati aroma, konsistensi, dan warna sediaan deodorant roll on ekstrak Ashitaba.

2. Uji daya sebar

Sebanyak 0,5 gram sediaan diletakkan pada alat uji daya sebar (kaca 1). Kaca 2 diletakkan diatas sediaan kemudian diberi beban seberat 100 gram selama 1 menit. Kemampuan menyebar sediaan ditentukan dengan mengukur diameter sebaran sediaan.

3. Uji daya lekat

Sebanyak 0,5 gram sediaan dioleskan pada kaca objek alat uji daya lekat. Kaca ditutup dengan kaca lainnya dan diberi beban $1 \mathrm{Kg}$ selama 5 menit. Selanjutnya beban diangkat dan pengait dilepaskan sehingga beban gantung terlepas. Waktu daya lekat ditentukan dengan menghitung waktu dari pengait dilepaskan hingga tempelan kedua kaca objek terlepas.

4. Uji pH

Uji $\mathrm{pH}$ dilakukan dengan mengukur $\mathrm{pH}$ sediaan menggunakan $\mathrm{pH}$ meter. 
Optimasi Formula Deodorant Roll-on Ekstrak Ashitaba dengan Simplex Lattice Design

Optimasi dilakukan dengan menggunakan software Design Expert. Nilai lower limit dan upper limit dimasukkan dalam software sehingga diperoleh sebanyak 8 run formula. Formula dibuat sesuai variasi yang ditentukan oleh software, kemudian dilakukan pengujian sifat fisik meliputi uji daya lekat, daya sebar, $\mathrm{pH}$, dan stabilitas sediaan. Hasil uji dimasukkan sebagai parameter respon untuk menentukan formula optimum deodorant roll on ekstrak ashitaba.

\section{Verifikasi Formula Optimum Deodorant Roll- on Ekstrak Ashitaba}

Hasil formula optimum yang diperoleh dari software Design Expert ${ }^{\circledR}$ 7.1.5 dibuat dan dilakukan uji sifat fisik. Hasil uji dibandingkan dengan prediksi respon dari software dengan menggunakan uji statistik.

\section{Hasil dan Pembahasan}

\section{Formulasi Deodorant Roll-on Ekstrak Ashitaba}

Pembuatan deodorant roll-on ekstrak ashitaba dilakukan menggunakan 8 formula yang diperoleh dari software Design Expert 7.1.5. Hasil uji sifat fisik 8 run formula dapat dilihat pada tabel 2.

Tabel 2. Hasil pengukuran sifat fisik deodorant roll-on ekstrak ashitaba

\begin{tabular}{|c|c|c|c|c|c|}
\hline Run & $\begin{array}{c}\text { Karbopol } \\
(\boldsymbol{\%})\end{array}$ & $\begin{array}{c}\text { TEA } \\
(\boldsymbol{\%})\end{array}$ & $\begin{array}{c}\text { Daya } \\
\text { Sebar } \\
(\mathbf{c m})\end{array}$ & $\begin{array}{c}\text { Daya } \\
\text { Lekat } \\
\text { (detik) }\end{array}$ & $\mathbf{p H}$ \\
\hline 1 & 1,25 & 1,25 & 2,60 & 164 & 6,30 \\
\hline 2 & 1,25 & 1,25 & 2,52 & 159 & 6,28 \\
\hline 3 & 2,25 & 0,25 & 2,36 & 367 & 4,71 \\
\hline 4 & 1,75 & 0,75 & 2,49 & 266 & 5,29 \\
\hline 5 & 0,25 & 2,25 & 6,89 & 2,72 & 8,23 \\
\hline 6 & 0,25 & 2,25 & 8,61 & 2,97 & 8,51 \\
\hline 7 & 0,75 & 1,75 & 3,53 & 766 & 7,37 \\
\hline 8 & 2,25 & 0,25 & 2,31 & 357 & 4,60 \\
\hline
\end{tabular}

Optimasi Formula Deodorant Roll-on Ekstrak Ashitaba

\section{Daya Sebar}

Data respon daya sebar dianalisis menggunakan software Design Expert ${ }^{\circledR}$ 7.5.1 Hasil uji ANOVA respon daya sebar dapat dilihat pada tabel 3, persamaan simplex lattice design dapat dilihat pada persamaan (1), dan grafik normal plot of residual dan grafik model campuran dua komponen dapat dilihat pada gambar 1 .

Tabel 3. Hasil uji ANOVA respon daya sebar dengan software Design Expert ${ }^{\circledR}$ 7.5.1

\begin{tabular}{|l|c|}
\hline \multicolumn{1}{|c|}{ Parameter } & Daya Sebar \\
\hline Model & 0,0011 \\
\hline Linear mixture & 0,0008 \\
\hline Lack of fit & 0,3952 \\
\hline Adj. R-square & 0,9079 \\
\hline Predicted R-square & 0,8164 \\
\hline Adeq. precision & 12,550 \\
\hline
\end{tabular}

$\mathrm{Y}=2,51 \mathrm{~A}+7,56 \mathrm{~B}-10,20 \mathrm{AB}$

Keterangan:

$\mathrm{Y}=$ respon daya sebar $(\mathrm{cm})$

$\mathrm{A}=\operatorname{karbopol}(\%)$

$\mathrm{B}=\mathrm{TEA}(\%)$

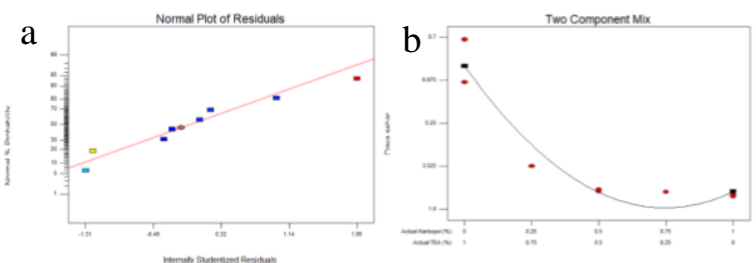

Gambar 1. Grafik normal plot of residual (a) dan model campuran dua komponen (b) respon daya sebar

\section{Daya Lekat}

Tabel 4. Hasil uji ANOVA respon daya lekat dengan software Design Expert ${ }^{\circledR}$ 7.5.1

\begin{tabular}{|l|c|}
\hline \multicolumn{1}{|c|}{ Parameter } & Daya Lekat \\
\hline Model & 0,0104 \\
\hline Linear mixture & 0,0058 \\
\hline Lack of fit & $<0,0001$ \\
\hline Adj. R-square & 0,8680 \\
\hline Predicted R-square & 0,4558 \\
\hline Adeq. precision & 8,538 \\
\hline
\end{tabular}

$\mathrm{LnY}=6,00 \mathrm{~A}+1,16 \mathrm{~B}+8,71 \mathrm{AB}-18,57 \mathrm{AB}(\mathrm{A}-\mathrm{B})$.

Keterangan:

$\mathrm{Y}=$ respon daya sebar $(\mathrm{cm})$

$\mathrm{A}=\operatorname{karbopol}(\%)$

$\mathrm{B}=\mathrm{TEA}(\%)$

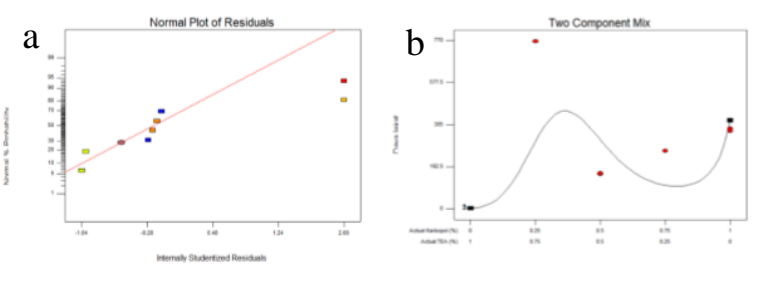


Gambar 2. Grafik normal plot of residual (a) dan model campuran dua komponen (b) respon daya lekat

3. $\mathbf{p H}$

Tabel 5. Hasil uji ANOVA respon $\mathrm{pH}$ dengan software Design Expert ${ }^{\circledR}$ 7.5.1

\begin{tabular}{|l|c|}
\hline \multicolumn{1}{|c|}{ Parameter } & pH \\
\hline Model & $<0,0001$ \\
\hline Linear mixture & $<0,0001$ \\
\hline Lack of fit & 0,2533 \\
\hline Adj. R-square & 0,9890 \\
\hline Predicted R-square & 0,9816 \\
\hline Adeq. precision & 47,449 \\
\hline
\end{tabular}

$\mathrm{Y}=4,53 \mathrm{~A}+8,29 \mathrm{~B}$

Keterangan:

$\mathrm{Y}=$ respon daya sebar $(\mathrm{cm})$

$\mathrm{A}=\operatorname{karbopol}(\%)$

$\mathrm{B}=\mathrm{TEA}(\%)$
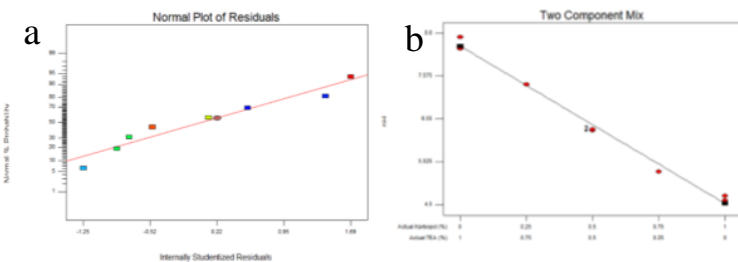

Gambar 3. Grafik normal plot of residual (a) dan model campuran dua komponen (b) respon $\mathrm{pH}$

\section{Penentuan Formula Optimum Deodorant Roll-on Ekstrak Ashitaba}

Kriteria yang digunakan dalam penentuan nilai optimum pada formulasi sediaan deodorant roll on ekstrak ashitaba dapat dilihat pada tabel 6.

Tabel 6. Kriteria penentuan formula optimum sediaan deodorant roll on ekstrak ashitaba dengan software Design Expert ${ }^{\circledR}$ 7.5.1

\begin{tabular}{|l|c|c|c|c|}
\hline Komponen & $\begin{array}{c}\text { Lower } \\
\text { Limit }\end{array}$ & $\begin{array}{c}\text { Upper } \\
\text { Limit }\end{array}$ & Goal & $\begin{array}{c}\text { Import } \\
\text { ance }\end{array}$ \\
\hline $\begin{array}{l}\text { Karbopol } \\
(\%)\end{array}$ & 0,25 & 2,25 & $\begin{array}{c}\text { Is in } \\
\text { range }\end{array}$ & 3 \\
\hline TEA (\%) & 0,25 & 2,25 & $\begin{array}{c}\text { Is in } \\
\text { range }\end{array}$ & 3 \\
\hline $\begin{array}{l}\text { Daya Sebar } \\
\text { (cm) }\end{array}$ & 5 & 8 & $\begin{array}{c}\text { Is in } \\
\text { range }\end{array}$ & 4 \\
\hline $\begin{array}{l}\text { Daya Lekat } \\
\text { (detik) }\end{array}$ & 4 & 766 & $\begin{array}{c}\text { Is in } \\
\text { range }\end{array}$ & 3 \\
\hline pH & 4,6 & 8 & $\begin{array}{c}\text { Is in } \\
\text { range }\end{array}$ & 3 \\
\hline
\end{tabular}

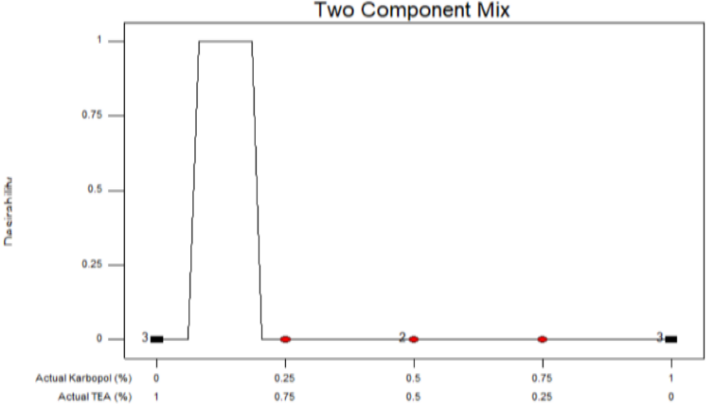

Gambar 4. Grafik optimasi campuran dua komponen pada formulasi sediaan deodorant roll on ekstrak ashitaba

\section{Verifikasi Formula Optimum Deodorant Roll- on Ekstrak Ashitaba}

Hasil uji statistik respon daya sebar, daya lekat, dan $\mathrm{pH}$ formula optimum hasil prediksi software Design Expert dan hasil percobaan dapat dilihat pada tabel 7 .

Tabel 7. Hasil uji statistik respon formula optimum deodorant roll-on ekstrak ashitaba

\begin{tabular}{|l|c|c|c|}
\hline Respon & Prediksi & Percobaan & p-value \\
\hline $\begin{array}{l}\text { Daya sebar } \\
\text { (cm) }\end{array}$ & 6,13 & $6,32 \pm 0,33$ & 0,661 \\
\hline $\begin{array}{l}\text { Daya lekat } \\
\text { (detik) }\end{array}$ & 43,05 & $44,67 \pm 3,94$ & 0,756 \\
\hline pH & 7,91 & $7,73 \pm 0,17$ & 0,464 \\
\hline
\end{tabular}

\section{Pembahasan}

\section{Formulasi Deodorant Roll-on Ekstrak Ashitaba}

Optimasi formula sediaan deodorant roll on ekstrak ashitaba dilakukan dengan metode simplex lattice design menggunakan software Design Expert ${ }^{\circledR}$ 7.1.5. Pada penelitian ini, bahan tambahan yang dioptimasi adalah karbopol dan TEA. Karbopol merupakan suatu polimer yang dapat bertindak sebagai agen pembentuk gel yang sangat berpengaruh terhadap sifat fisik sediaan yang terbentuk. Efektivitas pembentukan gelnya bergantung pada $\mathrm{pH}$ sediaan, sehingga TEA sebagai pengatur $\mathrm{pH}$ akan berpengaruh pula terhadap sifat fisik sediaan gel. Pada saat dilarutkan dalam air, karbopol bersifat basa dan strukturnya belum terionisasi. Penambahan TEA sebagai pengatur $\mathrm{pH}$ akan menggeser kesetimbangan ion sehingga campuran akan membentuk struktur garam yang 
larut air. Akibatnya, terjadi tolakan ionik pada gugus karboksilat pada karbopol sehingga dapat membentuk struktur gel yang ditandai dengan meningkatnya kekentalan (Osborne \& Amann, 1990).

Nilai rentang optimasi karbopol yang digunakan dalam penelitian ini adalah 0,25 2,25\%. Karbopol sebagai gelling agent memiliki rentang 0,5-2\% (Sulaiman \& Kuswahyuning, 2008). Rentang yang digunakan pada penelitian ini lebih rendah dari yang seharusnya karena disesuaikan dengan kekentalan sediaan yang diinginkan. Pada uji pendahuluan, dilakukan formulasi sediaan gel sebagai langkah awal untuk menentukan rentang optimasi. Hasil uji pendahuluan menunjukkan konsentrasi $0,5 \%$ karbopol menghasilkan gel yang terlalu kaku untuk sediaan deodorant roll on sehingga perlu penurunan konsentrasi yang digunakan dalam sediaan.

\section{Optimasi Formula Deodorant Roll-on Ekstrak Ashitaba}

\section{Daya Sebar}

Respon daya sebar merupakan salah satu parameter penting untuk mengetahui kemampuan sediaan untuk menyebar pada permukaan kulit. Berdasarkan data respon daya sebar, diperoleh analisis statistik seperti yang ditunjukkan pada tabel 3. Hasil ANOVA dari software Design Expert menunjukkan bahwa model gafik daya sebar adalah linear mixture. Nilai F model adalah 35,49 menunjukkan bahwa model signifikan. Model hanya dapat dipengaruhi oleh noise sebesar $0,11 \%$. Nilai $F$ lack of fit sebesar 1,29 menunjukkan bahwa lack of fit secara relatif tidak signifikan terhadap adanya error. Insignifikansi lack of fit dibutuhkan untuk mencapai model yang sesuai (fit). Pada penelitian ini, hanya sebesar $39,52 \%$ kemungkinan error mempengaruhi fitting model. Nilai predicted $R$-square dan adjusted $R$-square menunjukkan nilai yang sesuai karena tidak memiliki perbedaan lebih dari 0,2. Nilai adeq presicion mengukur rasio signal dengan noise. Nilai lebih dari 4 menunjukkan bahwa signal kuat dan tidak terpengaruh oleh noise.

Nilai positif $(+)$ pada persamaan simplex lattice design menunjukkan bahwa komponen memiliki pengaruh positif terhadap respon. Karbopol dan TEA secara individual memiliki pengaruh positif terhadap daya sebar, artinya semakin tinggi konsentrasi keduanya, daya sebar akan semakin tinggi. Namun, pengaruh negatif terjadi saat kedua komponen berinteraksi. Hal ini karena TEA sebagai pengatur $\mathrm{pH}$ memiliki pengaruh dalam pembentukan struktur gel karbopol. Struktur gel akan semakin kaku jika adanya interaksi antara karbopol dan TEA yang membentuk campuran dengan $\mathrm{pH}$ yang tepat (Rowe et al., 2009).

Gambar 1 menunjukkan bahwa data daya sebar terdistribusi normal ditunjukkan oleh nilai respon yang berada di sekitar garis seperti terlihat pada grafik normal plot of residual. Grafik campuran dua komponen menunjukkan bahwa daya sebar terbesar terjadi pada campuran yang mengandung konsentrasi karbopol paling rendah dan TEA paling tinggi. Daya sebar sediaan dengan konsentrasi TEA terendah mengalami penurunan hingga campuran kedua komponen menjadi 0,75:0,25 (karbopol:TEA), kemudian daya sebar terus meningkat hingga mencapai respon tertinggi pada konsentrasi TEA tertinggi $(100 \%)$. Hal ini terjadi karena penetralan berlebihan oleh TEA akan menyebabakan terjadinya presipitasi karena adanya reaksi counter ion. Hal ini menyebabkan penurunan viskositas sehingga daya sebar dapat meningkat (Osborne \& Amann, 1990).

Respon daya sebar berkaitan dengan viskositas sediaan. Sediaan dengan viskositas yang rendah biasanya memiliki daya sebar lebih luas karena sediaan cenderung lebih encer. Sebaliknya, sediaan dengan viskositas tinggi akan lebih kental sehingga kemampuan menyebarnya juga lebih rendah. Syarat daya sebar yang baik untuk sediaan topikal adalah 5-7 $\mathrm{cm}$ untuk sediaan semisolid, dan 3-5 cm untuk sediaan semistiff(Garg et al., 2002). Pada sediaan deodorant dengan bentuk roll-on, diperlukan tingkat kekentalan yang cukup agar sediaan dapat merata pada permukaan roll on. Sediaan yang terlalu kaku akan sulit untuk diaplikasikan pada kulit dengan bantuan roll on. Hal ini menjadi dasar penentuan kriteria daya sebar pada pembuatan sediaan deodorant roll on ekstrak ashitaba.

\section{Daya Lekat}

Respon daya lekat berkaitan dengan ketahanan sediaan pada permukaan kulit saat diaplikasikan. Data respon daya lekat pada 
penelitian ini memiliki rasio data lebih dari 10 sehingga perlu dilakukan transformasi data. Untuk mencapai model yang signifikan, digunakan tranformasi natural log. Hasil transformasi kemudian dianalisis statistik dengan hasil terlihat pada tabel 4. Nilai $\mathrm{p}$ model menunjukkan bahwa model signifikan. Hanya ada 1,04\% kemungkinan model dipengaruhi oleh noise. Nilai lack of fit signifikan, sehingga fitting model tidak terpenuhi. Nilai adjusted $R$-square dan predicted $R$-square cukup jauh, megindikasikan adanya masalah pada model atau data. Perlu perhatian terhadap adanya transformasi, reduksi model, data outlier, dan sebagainya. Namun nilai adeq presicion lebih dari 4 menunjukkan bahwa model dapat digunakan.

Berdasarkan persamaan simplex lattice design yang diperoleh, baik karbopol maupun TEA menunjukkan pengaruh yang positif terhadap respon daya lekat. Artinya, semakin tinggi nilai karbopol dan TEA, maka daya lekat semakin tinggi. Interaksi antara karbopol dan TEA dapat meningkatkan atau menurunkan respon daya lekat, tergantung dari konsentrasi keduanya. Pada konsentrasi karbopol yang lebih rendah atau sama dengan TEA, interaksi keduanya meningkatkan respon daya lekat, sedangkan saat konsentrasi karbopol lebih tinggi dibanding TEA, interaksi kedua komponen ini akan menurunkan respon daya lekat.

Gambar 2 menunjukkan data respon daya lekat tidak terdistribusi normal, namun grafik Box Cox menunjukkan bahwa transformasi data yang dilakukan sudah baik. Grafik model campuran dua komponen pada respon daya lekat menunjukkan nilai daya lekat terendah pada konsentrasi karbopol yang paling rendah.

\section{3. $\mathbf{p H}$}

Nilai pH merupakan salah satu parameter penting untuk sediaan yang diaplikasikan pada kulit, baik untuk sediaan topikal maupun sistemik. Untuk sediaan topikal, $\mathrm{pH}$ berpengaruh pada efek sediaan terhadap kulit. $\mathrm{pH}$ yang terlalu basa dapat menyebabkan iritasi sedangkan $\mathrm{pH}$ yang terlalu asam dapat menyebabkan kulit kering. Hasil uji ANOVA respon $\mathrm{pH}$ dapat dilihat pada tabel 5. Model yang terbentuk signifikan dengan model terpilih adalah linear mixture. Hanya terdapat $0,01 \%$ kemungkinan adanya pengaruh noise terhadap model. Nilai lack of fit tidak signifikan terhadap adanya eror, sehingga fitting model sesuai. Adjusted $R$-square dan predicted $R$-square memiliki nilai yang sesuai, dan nilai adeq presicion menunjukkan signal yang kuat sehingga tidak terpengaruh oleh noise.

Berdasarkan persamaan simplex lattice design respon $\mathrm{pH}$ pada persamaan (3), dapat diketahui bahwa kedua komponen memberikan pengaruh positif terhadap respon $\mathrm{pH}$. Komponen TEA memiliki pengaruh lebih besar terhadap respon $\mathrm{pH}$. Hal ini sesuai dengan sifat TEA sebagai agen pengatur $\mathrm{pH}$, yang memberikan efek peningkatan nilai $\mathrm{pH}$.

Gambar 3 menunjukkan data pada grafik normal plot of residual respon $\mathrm{pH}$ tersebar di sekitar garis linier sehingga disimpulkan bahwa data terdistribusi normal. Sedangkan grafik model campuran dua komponen menunjukkan bahwa semakin tinggi konsentrasi karbopol, $\mathrm{pH}$ sediaan semakin rendah dan semakin tinggi konsentrasi TEA, pH sediaan semakin tinggi.

\section{Penentuan Formula Optimum Deodorant Roll-on Ekstrak Ashitaba}

Berdasarkan persamaan simplex lattice design ketiga respon, maka dapat ditentukan nilai optimum komponen. Kriteria yang digunakan dalam penentuan nilai optimum pada formulasi sediaan deodorant roll on ekstrak ashitaba dapat dilihat pada tabel 6. Komposisi formula optimum yang diperoleh dengan kriteria tersebut adalah $0,45 \%$ karbopol dan $2,05 \%$ TEA. Nilai desirability formula optimum adalah 1 , menunjukkan bahwa software dapat memenuhi kriteria yang diinginkan oleh peneliti dengan sempurna (Ramadhani et al, 2017). Prediksi respon komponen formula optimum adalah daya sebar sebesar $6,131 \mathrm{~cm}$, daya lekat 43,05 detik, dan $\mathrm{pH} 7,91$. Grafik campuran dua komponen dari ketiga respon dapat dilihat pada gambar 6 .

\section{Verifikasi Formula Optimum Deodorant Roll- on Ekstrak Ashitaba}

Pembuatan formula optimum dilakukan dengan mengikuti komposisi formula optimum yang diberikan oleh software. Hasil pengujian respon daya sebar, daya lekat, dan $\mathrm{pH}$ formula optimum dapat dilihat pada tabel 7.

Hasil uji statistik yang dilakukan terhadap hasil respon prediksi formula optimum oleh software Design Expert dan hasil respon formula optimum hasil percobaan menunjukkan bahwa 
terdapat perbedaan yang tidak signifikan antara hasil prediksi dengan hasil percobaan ( $p>0,05)$. Hasil ini memverifikasi bahwa hasil prediksi yang diberikan oleh software adalah benar dan dapat diterima.

\section{Efektivitas Metode Simplex Lattice Design Dalam Optimasi Formula}

Metode simplex lattice design sudah sering diaplikasikan dalam berbagai bidang ilmu, salah satunya adalah pada bidang farmasi. Metode simplex lattice design dapat diterapkan pada optimasi berbagai campuran pelarut dalam ekstraksi metabolit sekunder dari bahan alam (Lestari et al, 2012; Harim, 2013; Setiawan, 2013; Anggasta, 2016). Metode ini juga dapat diaplikasikan dalam optimasi formula sediaan padat seperti tablet (Hadinugroho \& Fudholi, 2011), sediaan cair seperti sirup (Juliantoni, 2014), maupun sediaan semisolid seperti krim, salep, dan gel (Lestari et al, 2020; Kholisatunnisa, 2017; Rosyadi, 2013).

Deodorant roll-on ekstrak ashitaba yang dikembangkan pada penelitian ini adalah berupa sediaan semipadat berbentuk gel. Keseluruhan data optimasi formula deodorant roll-on ekstrak ashitaba menggunakan metode simplex lattice design menunjukkan hasil yang baik dan dapat diterima. Formula optimum yang diperoleh memiliki sifat fisik terbaik yang diperoleh dengan menggabungkan beberapa respon yang diteliti, dengan nilai desirability 1 . Hal ini sejalan dengan beberapa penelitian tentang optimasi gel dengan menggunakan metode simplex lattice design. Kuncahyo (2011) menyimpulkan bahwa optimasi carbopol dan HPMC pada formulasi gel ekstrak daun jambu mete (Anacardium occidentale) menggunakan metode simplex lattice design dapat diterima, ditunjukkan dengan perbedaan yang tidak signifikan antara hasil optimasi dengan hasil percobaan. Penelitian yang dilakukan oleh Martyasari et al (2019) menunjukkan hasil formula optimum gel hand sanitizer daun tekelan menggunakan metode simplex lattice design yang memenuhi sifat fisik yang baik. Optimasi formula gel antioksidan buah bligo (Benincasa hispida) menggunakan metode simplex lattice design menghasilkan formula optimum yang memenuhi syarat sifat fisik yang baik dengan nilai desirability 1 (Suryani et al, 2017).

\section{Kesimpulan}

Metode simplex lattice design dapat diaplikasikan untuk menentukan formula optimum sediaan roll-on ekstrak ashitaba. Formula optimum yang dihasilkan adalah pada komposisi 0,45\% karbopol dan 2,05\% TEA, dengan nilai respon daya sebar sebesar 6,32 $\pm 0,33$ $\mathrm{cm}$, daya lekat 44,67 $\pm 3,94$ detik, dan $\mathrm{pH}$ $7,73 \pm 0,17$. Hasil ini memenuhi kriteria sediaan yang baik, namun perlu pengujian lebih lanjut terkait dengan efektivitas sediaan dan tingkat penerimaan sediaan oleh pengguna.

\section{Ucapan Terima kasih}

Terimakasih penulis ucapkan kepada Universitas Mataram yang telah memberikan dukungan dana pada penelitian ini.

\section{Referensi}

Anggasta, WG (2016). Optimasi formula gel ekstrak etanolik daun sirih merah (Piper crocatum Ruiz. \& Pav.) dengan kombinasi basis karbomer dan CMC-Na menggunakan metode simplex lattice design. Skripsi. Universitas Gadjah Mada, Yogyakarta.

Enoki, T., Ohnogi, H., Nagamine, K., Kudo, Y., Sugiyama, K., Tanabe, M., Kobayashi, E., Sagawa, H. ... Kato, I., (2007). Antidiabetic activities of chalchones isolated from Japanese herbs, angelica keiskei. Journal of Agriculture and Food Chemistry, 55(16): 6013-6017.

Garg A, Aggarwal D, Garg S, \& Singla AK (2002). Spreading of semisolid formulations an update. Pharmaceutical Technology, 26: 84-105.

Hadinugroho, W. \& Fudholi, A. (2011). Optimasi formula tablet lepas lambat ibuprofen secara simplex lattice design dengan campuran carrageenan, kalsium sulfat, dan PVP-K30. Majalah Farmasi Indonesia, 22(4): 300-305.

Harim, EA (2013). Optimasi komposisi pelarut ekstraksi buah mahkota dewa (Phaleria 
macrocarpa (Scheff.) Boerl.) dengan parameter kadar flavonoid total secara simpelx lattice design. Skripsi. Universitas Sebelas Maret, Surakarta.

Inamori, Y., Baba, K., Tsujibo, H., Taniguchi, M., Nakata, K., \& Kozawa, M. (1991). Antibacterial activity of two chalchones, xanthoangelol and 4-hydroxyderricin, isolated from the root of angelica keiskei koidzumi. Chem. Pharm. Bull., 39(6): 1604-1605.

Juliantoni, Y. (2014). Optimasi formula sirup ekstrak etanolik daun kembang sepatu (Hibiscus rosa-sinensis L.) dengan bahan tambahan gliserin, sirupus simplex, dan CMC-Na. Skripsi. Universitas Gadjah Mada, Yogyakarta.

Kholisatunnisa, H. (2017). Optimasi formulasi salep ekstrak etanol daun sirsak (Annona muricata L.) terhadap bakteri penyebab bisul (Staphylococcus aureus) dengan metode simplex lattice design. Skripsi. Universitas Muhammadiyah Yogyakarta, Yogyakarta.

Kil, YS, Pham, ST., Seo, EK. \& Jafari, M. (2017). Angelica keiskei, an emerging medicinal herb with various bioactive constituents and biological activities. Archives of Pharmacal Research.

Kuncahyo, I. (2011). Optimasi campuran carbopol941 dan HPMC dalam formulasi sediaan gel ekstrak daun jambu mete secara simplex lattice design. Jurnal Farmasi Indonesia, 8(1): 1-12.

Kusuma, SAF, Iskandar, Y., \& Dewanti, MA. (2018). The ethanolic extract of ashitaba stem (angelica keiskei) as future antituberculosis. Journal of Advanced Pharmaceutical Technology and Research, 9(1): 37-41.

Lestari, ABS., Susanti, LU \& Dwiatmaka, Y., (2012). Optimasi pelarut etanol-air dalam proses ekstraksi herba pegagan (Centella asiatica (L.) Urban.) pada suhu terukur.
Bionatura-Jurnal Ilmu-ilmu Hayati dan Fisik, 14(2): 87-93.

Lestari, FA, Hajrin, W., \& Hanifa, NI. (2020). Optimasi formula krim ekstrak daun katuk (Sauropus androgynus) variasi konsentrasi asam stearat, trietanolamin, dan gliserin. Jurnal Kefarmasian Indonesia, 10(2): 110-119. DOI: https://doi.org/10.22435/jki.v10i2.2496.

Li, L., Aldini, G., Carini, M., Chen, CYO, Chun, HK, Cho, SM., \& Yeum, KJ., (2009). Characterisation, extraction efficiency, stability and antioxidant activity of phytonutrients in Angelica keiskei. Food chemistry, 115(1), 227-232.

Martyasari, NWR, Andayani, Y., \& Hajrin, W., (2019). Optimization of hand sanitizer gel formula of tekelan leaves extract (Chromoleana odorata) using simplex lattice design method. Bali Medical Journal, $\quad 8(3)$ : $\quad$ 769-773. DOI:10.15562/bmj.v8i3.1598.

Osborne, DW. \& Amann, AH., (1990). Topical Drug Delivery Formulation: Semisolid Products, Volume 92, 382-388. Marcel Dekker Inc., New York.

Paye, M., Barel, AO \& Maibach, HI (2001). Handbook of Cosmetics Sciences and Technology, $2^{\text {nd }}$ Edition, Marcel Dekker Inc, New York.

Ramadhani, RA., Riyadi, DHS, Triwibowo, B., \& Kusumaningtyas, RD. (2017). Review pemanfaatan design expert untuk optimasi komposisi campuran minyak nabati sebagai bahan baku sintesis biodesel. Jurnal Teknik Kimia Lingkungan, 1(1): 11-16.

Rosyadi, A. (2013). Optimasi kombinasi minyak atsiri bunga kenanga dengan herba kemangi dalam gel sebagai repelan nyamuk Aedes aegypti dengan metode simplex lattice design. Skripsi. Universitas Muhammadiyah Purwokerto, Purwokerto. 
Rowe, CR., Sheskey, PJ \& Quinn, ME. (2009). Handbook of Pharmaceutical Excipients, $6^{\text {th }}$ Edition. Pharmaceutical Press, London.

Setiawan, PYB (2013). Penerapan metode simplex lattice design dalam penentuan komposisi pelarut etanol-air pada proses ekstraksi daun papaya (Carica papaya) dengan respon aktivitas larvasida nyamuk Aedes aigypti. Skripsi. Universitas Gadjah Mada, Yogyakarta.

Suhartati, R. \& Virgianti, DP (2015). Daya hambat ekstrak etanol $70 \%$ daun ashitaba (Angelica keiskei) terhadap bakteri Staphylococcus aureus yang diisolasi dari luka diabetes. Jurnal Kesehatan Bakti Tunas Husada, 14(1): 162-171. DOI: http://dx.doi.org/10.36465/jkbth.v14 i1.134.

Sulaiman, TNS \& Kuswahyuning, R. (2008). Teknologi dan Formulasi Sediaan Semipadat. Pustaka Laboratorium Teknologi Farmasi Fakultas Farmasi Universitas Gadjah Mada, Yogyakarta, Indonesia.

Suryani, Nafisah A. \& Mana'an S. (2017). Optimasi Formula Gel Antioksidan Ekstrak Etanol Buah Bligo (Benincasa hispida) dengan Metode Simplex Lattice Design (SLD). Jurnal Farmasi Galenika (Galenika Journal of Pharmacy), 3(2): 150-156. doi:10.22487/j24428744.2017.v3.i2.8815

Wirasisya, DG, Juliantoni, Y. \& Hajrin, W., (2018). Pengaruh dua metode pengeringan pada aktivitas antibakteri ashitaba (angelica keiskei) terhadap Streptococcus mutans. Jurnal Farmasi Galenika, 4(1): 18-25.

Zhang, L., Jiang, Y., Pang, X., Hua, P., Gao, X., Li, Q. \& Li, Z., (2019). Simultaneous optimization of ultrasound-assisted extraction for flavonoids and antioxidant activity of angelica keiskei using response surface methodology (RSM). Molecules, 24(19): 3461. 